\title{
OS CRISTÃOS-NOVOS: O POVOAMENTO E A CONQUISTA DO SOLO BRASILEIRO (1).
}

\author{
JOSE GONÇALVES SALVADOR. \\ do Instituto Metodista de Ensino Superior, em \\ São Bernardo do Campo (SP).
}

Até agora muito pouco se sabia acerca do papel desempenhado pelos Cristãos-Novos (2) na colonização do Brasil. As obras que tratam do assunto fazem-rno de modo genérico e sem suficiente base documental, ou se restringem à Bahia e a Pernambuco escudando-se nas visitações do Santo Ofício em 1591 e 1618. Quase mais nada se escreveu alem disso, à falta de um pesquisador que quisesse levar avante o estudo. Quanto às Capitanias do Sul, nem é born dizer, ainda que as mesmas tenham sido de grande importância na conjuntura sócio-econômica de Portugal e das suas possessões no Atlântico Sul durante os dois primeiros séculos, fato este, aliás, que tambem anda a exigir melhor cuidado da parte dos historiadores.

$\mathrm{Na}$ verdade, quem quer que se interesse por desvendar o referido papel, logo encontrará uma série de problemas, caso esteja preso a falsas concepçōes sobre os judeus ou alheio ao espírito que vicejou no Brasil de antanho. Há-de perguntar-se, então: que lhes poderia oferecer o País, mal conhecido e sob o domínio de aborígenes e de animais ferozes? E, de mais a mais, como conseguiriam emigrar de Portugal se as leis lhes vedavam a saida? Que viriam fazer aqui, uma vez que os Forais estatuidos para os donatários só facultavam a distribuição de

(1). - Sob esse título virá a público dentre em breve uma obra de nossa autoria, em sequência a Cristãos-Novos, Jesuitas e lnquisição. É fruto de amplas pesquisas. Está dividida em duas partes, a primeira das quais trata do aspecto social, e a segunda, da conquista do solo brasileiro. São ao todo 400 páginas. Editora da Universidade de São Paulo e Livraria Pioneira.

(2). - Por Cristāos-Novos se entende os judeus portugueses que foram batizados ao tempo de el-rei d. Manuel. A comunidade somava cerca de 400.000 almas. Os seus descendentes tambem eram considerados assim. 
terras a quem fosse "cristão"? Afora o pau-brasil, reservado em carater de exclusividade para a Coroa, o que mais thes sobraria para negociarem'?

Apesar de tudo, no entanto, os hebreus vieram. Não importa se judaizantes, se apóstatas ou se cristāos sinceros. A diáspora sucedeu realmente, sobretudo depois que a Inquisição se estabeleceu no Reino. Em ondas sucessivas eles foram escapando para as nações da Europa, bordos da Africa ao Norte e a Ocidente, e para as Indias de Castela. E por que não para o Brasil? Seria este último, por ventura, um lugar destinado apenas à recepção de criminosos, conforme erroneamente ainda admitem as pessoas mal esclarecidas? Toda a evidência histórica revela coisa bem diversa. O regime das capitanias hereditárias jamais vingaria se dependesse de degredados, e nem eles somavam tantos com respeito aos colonos que imigraram por expontânea vontade.

Ninguem, talvez, melhor do que os judeus portugueses se foi apercebendo das possibilidades ensejadas pela Terra de Santa Cruz. Eles contactaram com a mesma desde os albores do descobrimento. Fernão de Loronha e o seu consórcio de Cristãos-Novos detiveram o primeiro contrato do pau-brasil, o qual, tempos depois, passou sucessivamente a outros da progênie. Entre os mais antigos povoadores contam-se, por exemplo, nomes do porte de Filipe de Guilen e de Francisco Raposo, nas chamadas Capitanias de Cima, ao passo que, em São Vicente, encontramos os de Estêvão Gomes da Costa, Lopo Dias, Tristão Mendes e Manuel Veloso de Espinha. Quando se efetuou a visitação do Santo Ofício à Bahia e a Pernambuco, de 1591 a 1595, o número era já bastante significativo. Uma década mais tarde, Dirk de Ruiter confirma-lhes a presença do Amazonas ao Rio da Prata, e o vigário-geral padre Manuel Temudo, em 1632, relata aos inquisidores de Lisboa que "a maior parte dos habitantes são judeus", destacando, alem disto, que muites possuem boa riqueza e desfrutam de invejavel posição social (3) . Em virtude da união das Coroas na Península, multiplicara-se o acervo com a chegada de judeus espanhóis.

Contudo, o nosso interesse voltou-se para as Capitanias do Sul, c mais especificamente para São Paulo e Rio de Janeiro. As duas oferecem contrastes admiráveis. A distância entre elas é curta. Uma, no entanto, localiza-se no planalto; a outra, no litoral. Os climas diferem. Em ambas vingaram gêneros de vida bem distintos. Naquela - predominou o sertanismo e a policultura, e nesta a grande lavoura canavieira. São Paulo estava voltado para o hinterland e o Rio de Janeiro para o exterior. Se, por conseguinte, os judeus vieram para cá, como se comportariam nas duas áreas?

(3). - Inquisição de Lisboa, Caderno do Promotor $n^{9} 15$, fl. 45 e segs. 
Por estranho que pareça, vieram, e não foram poucos. No Rio de Janeiro já desde a fundação da cidade. Arrolamos dez famílias troncos nos anos de 1560 a 1580 , e assim por diante. Não foi, pois, à toa, que frei Diogo do Espírito Santo escreveu dali ao Santo Ofício, em 1625 , preocupado com a situação local. De fato a comunidade israelita caminhava sem detença, em quantidade e em prestígio. No lustre de 1695 o navegante Frogger computou-os em três quartos da população. O surto demográfico tinha razōes nos conflitos ao Norte, com os holandeses, e no Sul com o progresso do trato angolano-rioplatense, figurando de permeio a Guanabara. Depois aconteceu a fundação da Colônia do Sacramento e o descobrimento aurífero nas Minas Gerais .

Mas, São Paulo, nos campos de Piratininga, isolado pela Serra do Mar e vegetando na pobreza, que atrativo poderia ter para os judeus, se, como já se disse, eram amantes de uma vida facil e mais inclinados ao comércio do que à agricultura? Pergunta-se, de igual modo: que lhes ofereciam de melhor, na época, Luanda e Buenos Aires? E todavia, eles se estabeleceram em ambas, assim como tambem no cimo da Paranapiacaba. Aí está a documentação paulistana a confirmá-lo. As Atas da Câmara mencionam o fato. Havia um rol dos que pagavam as "fintas". Em 1618 certo Francisco Lopes Pinto recusou-se a entrar com a sua cota individual e solicitou que lhe tirassem o nome do livro, pois não se considerava elemento da estirpe. Estava registrado, precisamente, à folha 21 , no verso. Quantos, por isso, não figurariam nas páginas anteriores, e mesmo nas seguintes? $\mathrm{E}$, de mais a mais, fontes de origem hispano-americana, quer jusuítica quer oficial, abundam em referências ao fluxo hebraico em São Paulo. O padre Francisco Crespo, em 1629, e o governador do Rio da Prata, em 1631, declaram que "muchos delos son christianos nuevos", afirmativa que os inquisidores de Lima, no Peru, tornam a repisar um decênio depois.

Isto posto, verifica-se que laboram em erro quantos admitam o alto acervo de Cristãos-Velhos na colonização, em detrimento da progênie hebraica, estribando-se nas leis que exigiam pureza de sangue (ou étnica) para o ingresso na vida eclesiástica, nas Ordens nobiliárquicas e no funcionalismo. Porque, a ser assim, os seus respectivos genitores e todos os familiares estariam isentos do defeito impeditivo, mas o que se constata, na verdade, é a existência de numerosos clérigos e de pessoas nobilitadas, embora de linhagem judia. O padre José de Anchieta e Salvador Correia de Sá e Benevides constituem bom exemplo.

A evidência se aplica de igual modo a muitos dos governadores que nos mandaram de Portugal, pois não pertenciam à nobreza sanguínea do Reino e nem às primeiras elites. Eram elementos da mé- 
dia nobreza, e daí para baixo, tais como Tomé de Sousa, Gomes Freire de Andrade, o governador-geral Afonso Furtado de Castro do Rio, e outros. Nem podemos acompanhar o genealogista Pedro Taques na crença de que os companheiros de Martim Afonso de Sousa eram nobres de tradicional linhagem e que, estabelecendo-se na Capitania de São Vicente, hajam conservado a pureza. Nada mais falso! Basta iembrar o casamento de Jerônimo Leitão com a judia Inês Mendes, e o do hebreu, em São Paulo, Francisco Vaz Coelho, com a filha de Antônio de Proença, todos bem antes de findar-se o século XVI. No Rio de Janeiro o mesmo sucedeu com o velho Salvador Correia de Sá, e na Bahia com o fidalgo Henrique Moniz Teles.

E de suma valia, então, uma análise do problema filogenético ao tempo de nosso embasamento étnico-social. Ressalte-se inicialmente a falsa idéia segundo a qual os Cristãos-Novos, assim como os da etnia ariana, repudiavam os casamentos mistos. Observe-se, contudo, que o semita hebreu nunca foi rigorosamente fechado a tais enlaces enquanto viveu em Portugal. A exogamia atingiu a todas as classes, e nos Brasil ainda mais, em virtude da liberdade que vicejava no País. A princípio escassearam as mulheres brancas. Judeus e cristãos uniram-se a indígenas. Novos imigrantes formaram o lar casando-se com mamelucas. As famílias, por fim, acabaram misturando-se. No Rio de Janeiro os laços conjugais abrangeram, inclusive, as escravas negras, não escapando ao fato nem mesmo alguns judeus radicados na capitania. Por exemplo, o padre Francisco de Paredes, ainda que impedido pelo sangue da mãe, a preta Leonor, e pelo do pai, Luís de Paredes, semita judeu, tornou-se sacerdote. Mas, não obstante, a sociedade fluminense foi sempre mais exclusivista que a de São Paulo, quer da parte de uma, quer da outra etnia branca. Tambem dois tipos de vida tiveram lugar nas duas áreas.

E inegavel, pois, a presença do Cristāo-Novo nas Capitanias de Baixo, como nas de Cima. Ele veio e exerceu os mais diversos misteres, desde o de modesto trabalhador. Foi canoeiro, sapateiro, mestre de açúcares, agricultor, funcionário público, negociante, etc. $\mathrm{Na}$ zona dos canaviais, aparece entre os senhores de engenho, ao passo que em São Paulo envergou e endumentária do sertanista e foi policultor. Bandeirantes insignes se revelaram Sebastião de Freitas, Pedro Vaz de Barros, André Fernandes e tantos mais, todos de linhagem israelita.

A princípio os estabelecimentos se formaram ao longo do litoral. As comunicaçōes com a Metrópole o exigiam. As terras bastavam, muito embora destinadas à agricultura do tipo plantation. Tinham, porem, çue ser conguistadas aos indígenas. Por isso os judeus entra- 
ram na luta com os seus bens e pessoas ao lado dos capitães-mores. Era esta, de mais a mais, uma das maneiras para obterem sesmarias, apesar de que os Forais só permitiam a mercê a quem fosse "cristão". O certo é que, ao fim de alguns decênios, excelentes propriedade na zona rural, nas vilas e nas cidades, achavam-se sob o seu domínio. Estêvão Gomes da Costa teve uma das mais antigas fazendas à entrada de São Vicente. No planalto os chãos dos Vaz de Barros perdiam-se de vista. No Espírito Santo e no Rio de Janeiro os engenhos de conhecidos judaizantes figuravam entre os melhores. Na Guanabara as casas assobradadas de Antônio Gomes Vitória se salientavam porto a dentro.

Assim, tambem, nós os vamos encontrar na defesa do território contra o invasor estrangeiro, aliado comumente ao indígena, a exemplo dos franceses de Vilegagnon, e de outros na Paraiba e no Maranhão. Futuras mercês, simbolisadas por terras ou por títulos honorí$\cos$ os incitavam à luta, alem de que se sentiam irmanados com os restantes colonos e, todos juntos, súditos fieis da Casa de Bragança. E o exemplo de Manuel Veloso de Espinha. em São Vicente e no Rio de Janeiro; de Belchior Roiz nas campanhas nordestinas. Na Bahia o riquíssimo Pero Garcia morre de armas na mão combatendo os holandeses. Em Pernambuco sobem a dezenas os que fustigam o batavo intruso. Estão, mais uma vez, ao lado da Coroa .

Nas Capitanias do Sul o exemplo por excelência é dado pelos bandeirantes paulistas. Eles foram escravocratas não só por motivos econômicos, mas pclíticos, igualmente. Ao depredarem as "reduções" no Paraguai, estavam convencidos de que as terras ocupadas pelos jesuitas e demais castelhanos, eram de Portugal. Note-se, alem disto, a simpatia que os judeus nutriam para com o prior do Crato e os condes da Vidigueira-Monsanto e simultaneamente de repulsa a Filipe II, nascidas ao tempo das pretensões ao trono português, vago pela morte do Cardeal-Rei. Ipso facto, os paulistas nunca aderiram de coração aos habsburgos madrilenos. Nem olvidemos a euforia que causou a São Paulo o advento do Encoberto, encarnado em d. João IV, conforme a história patenteia. A aclamação de Amador Bueno, de ascendência espanhola, estaria fadada a fracasso, por isso mesmo, e ele bem o sabia.

Em conclusão, os hebreus portugueses trouxeram um notavel subsídio ao povoamento, à cultura, ao recuo dos limites impostos pelo acordo de Tordesilhas, à economia do País e, enfim, à administração em todos os degraus, conforme está demonstrado amplamente em nossa obra Os Cristäos-Novos: povoamento e conquista do solo brasileiro. Nela, tambem, os aspectos negativos da sua atuação. 